\title{
Molecular Structure of
}

\section{1,2-Dibenzoyl-1' $, 2^{\prime}, 3^{\prime}, 4^{\prime}, 5^{\prime}$-pentamethylruthenocene Dioxime Hydrochloride}

\author{
Stefan Vanicek, Daniela Eisenstecken, Holger Kopacka, Klaus Wurst, and Benno Bildstein \\ Institute of General, Inorganic and Theoretical Chemistry, University of Innsbruck, Center for Chemistry and Biomedicine, \\ Innrain 80-82, 6020 Innsbruck, Austria
}

Correspondence should be addressed to Benno Bildstein; benno.bildstein@uibk.ac.at

Received 29 April 2013; Accepted 3 October 2013

Academic Editors: M. Du, L. R. Gomes, and A. M. Romerosa-Nievas

Copyright (c) 2013 Stefan Vanicek et al. This is an open access article distributed under the Creative Commons Attribution License, which permits unrestricted use, distribution, and reproduction in any medium, provided the original work is properly cited.

The dioxime of 1,2-dibenzoylpentamethylruthenocene is synthesized from its parent diketone and hydroxylamine under standard basic conditions. The slightly air-sensitive product is crystallized in the form of its monohydrochloride. The solid-state structure is the first example of a dioxime monohydrochloride showing a typical metallocene core with peripheral intramolecular $\mathrm{N}-\mathrm{H}-\mathrm{N}$ and $\mathrm{O}-\mathrm{H}-\mathrm{Cl}$ hydrogen bonding.

\section{Introduction}

Simple vicinal dioximes represent the well-known chelating ligands with numerous applications in coordination chemistry $[1,2]$, catalysis $[3,4]$, and supramolecular chemistry [5-7]. Based on our earlier work $[8,9]$ with metallocene metalloligands, we address in this work a new organometallic hybrid dioxime composed of a redox-responsive ruthenocene core and conjugated dioxime functional groups. Synthetic and structural properties in solution and in the solid state are reported.

\section{Materials and Methods}

2.1. 1,2-Dibenzoyl-1' $2^{\prime} 2^{\prime}, 3^{\prime}, 4^{\prime}, 5^{\prime}$-pentamethylruthenocene Dioxime. In the first Schlenk vessel, a solution of 1,2-dibenzoyl-1 $1^{\prime}, 2^{\prime}, 3^{\prime}, 4^{\prime}, 5^{\prime}$-pentamethylruthenocene $[8,9](0.200 \mathrm{~g}$, $0.40 \mathrm{mmol}$ ) in dry ethanol $(5 \mathrm{~mL})$ was prepared at room temperature. In the second Schlenk vessel, a solution of hydroxylamine hydrochloride $(0.400 \mathrm{~g}, 5.76 \mathrm{mmol})$ in dry ethanol $(5 \mathrm{~mL})$ and freshly distilled, dry pyridine $(4.96 \mathrm{mmol}$, $0.40 \mathrm{~mL}$ ) was similarly prepared. Under protection from air, the two solutions were combined and heated to reflux for 45 minutes. Workup is as follows: pyridine and most volatile materials were removed on a vacuum line. Under protection from air, the residue was repeatedly extracted with small portions $(2 \mathrm{~mL})$ of warm, dry ethanol. The ethanolic solutions were filtered through a syringe filter, and the combined extracts were cooled in an ice/water-bath for crystallization. Without protection from air, the crystallized product was filtered off, washed with two portions of cold water, and dried under vacuum, affording $0.125 \mathrm{~g}$ of orange-yellow 1,2dibenzoyl-1', $2^{\prime}, 3^{\prime}, 4^{\prime}, 5^{\prime}$-pentamethylruthenocene dioxime in $57.9 \%$ yield. Note that this compound is air-stable in the solid state but slightly air-sensitive in solution. M.p.: $163^{\circ} \mathrm{C}$ (dec.).

${ }^{1} \mathrm{H}$ NMR $\left(300 \mathrm{MHz}, \mathrm{CD}_{2} \mathrm{Cl}_{2}\right)$ : d 1.78 (s, $\left.15 \mathrm{H}, \mathrm{Cp}^{*}\right), 4.43$ (d, 2H, Cp), 4.56 (t, 1H, Cp), 7.57 (br s, 10H, phenyl), 12.16 (s, 2H, N-OH). ${ }^{13} \mathrm{C}$ NMR $\left(75 \mathrm{MHz}, \mathrm{CD}_{2} \mathrm{Cl}_{2}\right): \mathrm{d}$ $11.2\left(\mathrm{Cp}^{*}\right), 78.1(\mathrm{Cp}), 79.8(\mathrm{Cp}), 81.2\left(\mathrm{Cp}^{*}\right), 88.7(\mathrm{Cp})$; 128.5, 129.2, 130.2, 131.0 (phenyl); $158.0(\mathrm{C}=\mathrm{N}-\mathrm{OH})$. LSIMS: $m / z 541.14\left(\mathrm{M}^{+}+\mathrm{H}\right)$. Single crystals of the hydrochloride of 1,2-dibenzoyl-1' $, 2^{\prime}, 3^{\prime}, 4^{\prime}, 5^{\prime}$-pentamethylruthenocene dioxime were obtained at room temperature from a solution of dichloromethane/ $n$-hexane $(\mathrm{v} / \mathrm{v}=1 / 1)$.

2.2. X-Ray Crystallography: Single-Crystal X-Ray Measurements and Structure Determination (Table 1). The data collection was performed on a Nonius Kappa CCD diffractometer equipped with graphite-monochromatized $\mathrm{Mo}-K_{\alpha}$-radiation 
TABLE 1: Crystallographic data.

\begin{tabular}{|c|c|c|}
\hline Empirical formula & $\mathrm{C}_{29} \mathrm{H}_{31} \mathrm{ClN}_{2} \mathrm{O}_{2} \mathrm{Ru}$ & \\
\hline Formula weight & 576.08 & \\
\hline Temperature & $233(2) \mathrm{K}$ & \\
\hline Wavelength & $0.71073 \AA$ & \\
\hline Crystal system & Monoclinic & \\
\hline Space group & $\mathrm{P} 2_{1} / \mathrm{c}($ no. 14$)$ & \\
\hline \multirow[t]{3}{*}{ Unit cell dimensions } & $a=16.6035(2) \AA$ & $\alpha=90^{\circ}$ \\
\hline & $b=16.6935(4) \AA$ & $\beta=105.432(2)^{\circ}$ \\
\hline & $c=20.0607(4) \AA$ & $\gamma=90^{\circ}$ \\
\hline Volume & $5359.77(18) \AA^{3}$ & \\
\hline$Z$ & 8 & \\
\hline Density (calculated) & $1.428 \mathrm{~g} / \mathrm{cm}^{3}$ & \\
\hline Absorption coefficient & $0.713 \mathrm{~mm}^{-1}$ & \\
\hline$F(000)$ & 2368 & \\
\hline Crystal size & $0.34 \times 0.15 \times 0.09 \mathrm{~mm}^{3}$ & \\
\hline Theta range for data collection & 1.27 to $24.94^{\circ}$ & \\
\hline Index ranges & $-19 \leq h \leq 19,-19 \leq k \leq 19,-23 \leq l \leq 18$ & \\
\hline Reflections collected & 30131 & \\
\hline Independent reflections & $9334[R($ int $)=0.0359]$ & \\
\hline $\operatorname{Reflections}[I>2 \operatorname{sigma}(I)]$ & 7629 & \\
\hline Completeness to theta $=24.94^{\circ}$ & $99.6 \%$ & \\
\hline Absorption correction & None & \\
\hline Refinement method & Full-matrix least-squares on $F^{2}$ & \\
\hline Data/restraints/parameters & $9334 / 6 / 665$ & \\
\hline Goodness-of-fit on $F^{2}$ & 1.037 & \\
\hline Final $R$ indices $[I>2 \operatorname{sigma}(I)]$ & $R_{1}=0.0379, w R_{2}=0.0880$ & \\
\hline$R$ indices (all data) & $R_{1}=0.0518, w R_{2}=0.0935$ & \\
\hline Largest diff. peak and hole & 0.428 and $-0.784 \mathrm{e} \cdot \AA^{-3}$ & \\
\hline
\end{tabular}

( $\lambda=0.71073 \AA)$ and a nominal crystal to area detector distance of $36 \mathrm{~mm}$. Intensities were integrated using DENZO and scaled with SCALEPACK [10]. Several scans in the $\varphi$ and $\omega$ directions were made to increase the number of redundant reflections, which were averaged in the refinement cycles. This procedure replaces an empirical absorption correction. The structures were solved with direct methods (SHELXS-86) and refined against $F^{2}$ (SHELX-97) [11]. Hydrogen atoms at carbon atoms were added geometrically and refined using a riding model, whereas the hydrogen atoms at nitrogen and oxygen atoms were exactly localized and refined isotropically with bond restraints of $89 \mathrm{pm}$ for $\mathrm{N}-\mathrm{H}$ and $83 \mathrm{pm}$ for $\mathrm{O}-\mathrm{H}$, respectively. The refinement of $\mathrm{N}-\mathrm{H}$ distances without bond restraints leads to bond lengths of 99 and $103 \mathrm{pm}$ for N2-H and N4-H. All nonhydrogen atoms were refined with anisotropic displacement parameters.

\section{Results and Discussion}

Synthetically, 1,2-dibenzoyl-1', $2^{\prime}, 3^{\prime}, 4^{\prime}, 5^{\prime}$-pentamethylruthenocene dioxime is obtained in $58 \%$ isolated yield from the diketone by reaction with hydroxylamine hydrochloride and pyridine. This dehydrative condensation is a standard procedure for dioxime formation; however, protection from air is mandatory in this case due to the sensitivity of the product towards dehydration/dehydroxylation promoted by the strong electron-donating effect of the pentamethylruthenocene moiety. Structural properties in solution are in line with expectations, as shown by NMR spectroscopy. Interestingly, suitable single crystals for $\mathrm{X}$-ray structure analysis were obtained only for the monohydrochloride of the product, but not for the neutral dioxime. In principle, oximes are acid-sensitive and give rise to the Beckmann rearrangement in the presence of electrophiles; therefore, this is quite unusual. There are many structural reports on dioximes, including studies focusing on their supramolecular chemistry based on $\mathrm{N}-\mathrm{H}-\mathrm{O}$ hydrogen-bonded architectures $[12,13]$, but to the best of our knowledge no protonated dioxime has been characterized in the solid state.

The compound crystallizes in the centrosymmetric space group $\mathrm{P} 2{ }_{1} / \mathrm{c}$ with a pair of planar chiral enantiomeric molecules in the asymmetric unit (Figure 1). The planar chirality is due to the resolved, localized protonation of the nitrogen atoms $\mathrm{N} 2$ and $\mathrm{N} 4$, thereby forming two chemically nonequivalent hydroxyliminoyl substituents in the 1,2position of the lower cyclopentadienyl ring. Whereas a local pseudosymmetry of the monoprotonated 1,2-bis(hydroxyliminoyl)cyclopentadienide might seem evident, this symmetry is broken by the position of the five methyl groups 

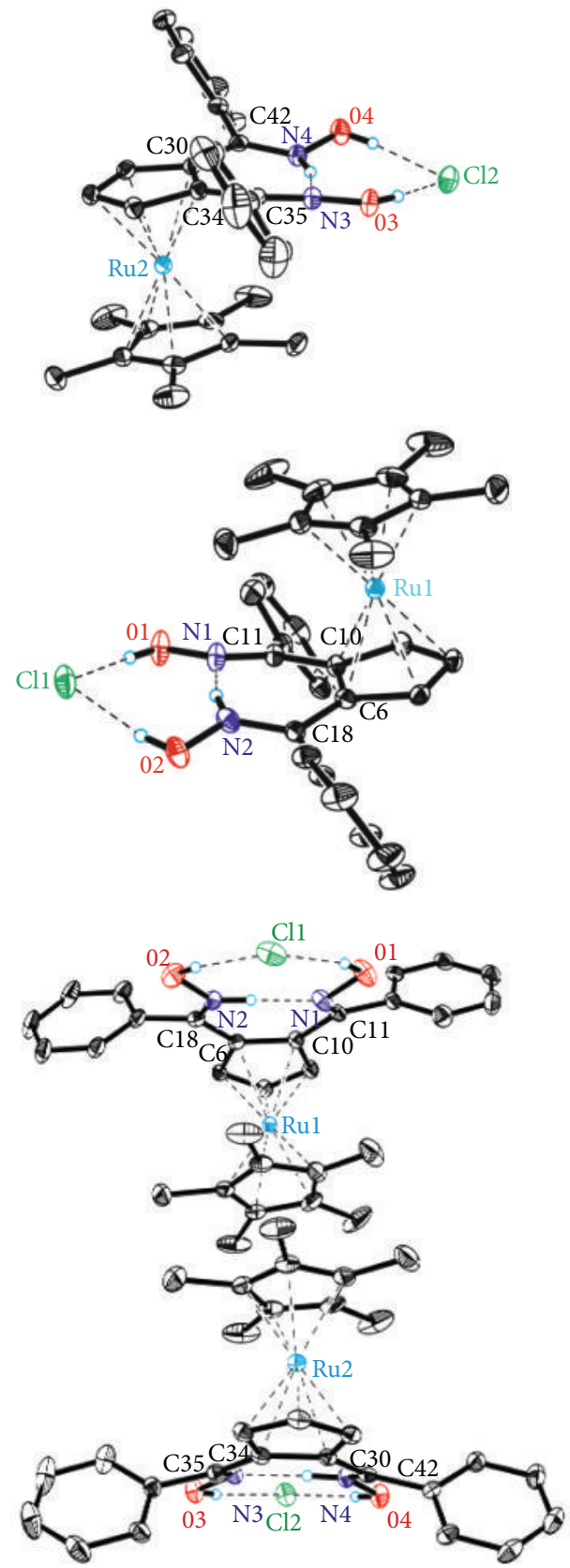

FIgURE 1: Two views of the enantiomeric pair of planar chiral molecules in the asymmetric unit, hydrogen atoms at carbon atoms are omitted for clarity and thermal ellipsoids are drawn on $20 \%$ probability level.

of the $\mathrm{Cp}^{*}$ ligand of the ruthenocenedioxime molecule. Surprisingly, the $\mathrm{N}-\mathrm{H}$ bonds are well ordered in the crystal lattice, and the influence of protonation leads to the increase of the $\mathrm{N}-\mathrm{O}$ bond of around $1.6 \mathrm{pm}$ and the decrease of the $\mathrm{C}=\mathrm{N}$ double bond of around $0.5 \mathrm{pm}$ for each molecule (Table 2). As a consequence of the strong intramolecular $\mathrm{N}-\mathrm{H}-\mathrm{N}$ bonds, the $\mathrm{C}=\mathrm{N}$ double bonds are twisted to the conjugated cyclopentadienyl planes, shown by torsion angles of averaged $\pm 18^{\circ}$ (Table 3 ). The chloride anions are connected by two strong intramolecular $\mathrm{O}-\mathrm{H}-\mathrm{Cl}$ hydrogen
TABLE 2: Atomic coordinates $\left(\times 10^{4}\right)$ and displacement parameters (in $\AA^{2} \times 10^{3}$ ).

\begin{tabular}{|c|c|c|c|c|}
\hline & $x$ & $y$ & $z$ & $U(\mathrm{eq})$ \\
\hline $\mathrm{Ru}(1)$ & $4452(1)$ & $6377(1)$ & 2455(1) & $33(1)$ \\
\hline $\mathrm{Ru}(2)$ & $687(1)$ & 3922(1) & $2622(1)$ & $36(1)$ \\
\hline $\mathrm{Cl}(1)$ & $6234(1)$ & $3774(1)$ & $4498(1)$ & $71(1)$ \\
\hline $\mathrm{Cl}(2)$ & $-1164(1)$ & $6607(1)$ & $607(1)$ & $58(1)$ \\
\hline $\mathrm{O}(1)$ & $6349(2)$ & 4023(2) & $3046(2)$ & $67(1)$ \\
\hline $\mathrm{O}(2)$ & $6179(2)$ & $5508(2)$ & 4802(1) & $66(1)$ \\
\hline $\mathrm{O}(3)$ & $-1146(2)$ & 6361(1) & 2103(1) & $50(1)$ \\
\hline $\mathrm{O}(4)$ & $-1111(2)$ & $4875(2)$ & $327(1)$ & $54(1)$ \\
\hline $\mathrm{N}(1)$ & $6059(2)$ & $4801(2)$ & $3071(2)$ & $50(1)$ \\
\hline $\mathrm{N}(2)$ & $5986(2)$ & $5679(2)$ & 4108(1) & $47(1)$ \\
\hline $\mathrm{N}(3)$ & $-875(2)$ & $5575(2)$ & $2077(1)$ & $42(1)$ \\
\hline $\mathrm{N}(4)$ & $-859(2)$ & $4695(2)$ & 1020(1) & $41(1)$ \\
\hline$C(1)$ & $3673(2)$ & $5572(2)$ & $2869(2)$ & $51(1)$ \\
\hline$C(2)$ & $3357(2)$ & $6349(2)$ & $2854(2)$ & $48(1)$ \\
\hline$C(3)$ & $3119(2)$ & $6629(2)$ & $2170(2)$ & $48(1)$ \\
\hline$C(4)$ & $3293(2)$ & 6015(3) & $1736(2)$ & 63(1) \\
\hline$C(5)$ & $3633(2)$ & $5346(2)$ & $2182(2)$ & $61(1)$ \\
\hline$C(6)$ & $5686(2)$ & $6577(2)$ & $3154(2)$ & $37(1)$ \\
\hline $\mathrm{C}(7)$ & $5355(2)$ & $7338(2)$ & $2874(2)$ & $36(1)$ \\
\hline$C(8)$ & $5227(2)$ & $7322(2)$ & $2150(2)$ & $40(1)$ \\
\hline $\mathrm{C}(9)$ & $5476(2)$ & $6560(2)$ & $1967(2)$ & $41(1)$ \\
\hline $\mathrm{C}(10)$ & $5761(2)$ & $6083(2)$ & $2574(2)$ & $35(1)$ \\
\hline $\mathrm{C}(11)$ & $6059(2)$ & $5251(2)$ & $2552(2)$ & $39(1)$ \\
\hline $\mathrm{C}(12)$ & $6346(2)$ & $4987(2)$ & $1945(2)$ & $41(1)$ \\
\hline $\mathrm{C}(13)$ & $6933(2)$ & $5443(2)$ & $1736(2)$ & $44(1)$ \\
\hline $\mathrm{C}(14)$ & $7227(2)$ & 5203(3) & $1183(2)$ & $54(1)$ \\
\hline$C(15)$ & $6942(3)$ & 4519(3) & $839(2)$ & $67(1)$ \\
\hline$C(16)$ & $6359(3)$ & 4059(3) & $1030(2)$ & $72(1)$ \\
\hline $\mathrm{C}(17)$ & $6057(2)$ & $4290(2)$ & $1585(2)$ & $63(1)$ \\
\hline $\mathrm{C}(18)$ & $5871(2)$ & $6409(2)$ & $3894(2)$ & $38(1)$ \\
\hline $\mathrm{C}(19)$ & $5891(2)$ & $7077(2)$ & $4378(2)$ & $44(1)$ \\
\hline$C(20)$ & $5338(2)$ & $7096(2)$ & $4795(2)$ & $51(1)$ \\
\hline $\mathrm{C}(21)$ & $5310(3)$ & 7762(3) & $5192(2)$ & $68(1)$ \\
\hline$C(22)$ & $5839(3)$ & $8396(3)$ & $5198(2)$ & $79(1)$ \\
\hline$C(23)$ & $6415(3)$ & $8365(3)$ & $4812(2)$ & $78(1)$ \\
\hline$C(24)$ & $6434(2)$ & 7713(3) & $4396(2)$ & $62(1)$ \\
\hline$C(25)$ & $1578(2)$ & 4343(3) & $2074(2)$ & $58(1)$ \\
\hline$C(26)$ & $1903(2)$ & $3642(2)$ & $2456(2)$ & $55(1)$ \\
\hline $\mathrm{C}(27)$ & $2006(2)$ & $3805(2)$ & $3167(2)$ & $49(1)$ \\
\hline $\mathrm{C}(28)$ & $1743(2)$ & $4599(2)$ & $3228(2)$ & $50(1)$ \\
\hline$C(29)$ & $1480(2)$ & $4941(2)$ & $2557(2)$ & $56(1)$ \\
\hline $\mathrm{C}(30)$ & $-580(2)$ & $3782(2)$ & $1959(2)$ & $35(1)$ \\
\hline $\mathrm{C}(31)$ & $-274(2)$ & $3009(2)$ & $2231(2)$ & $40(1)$ \\
\hline$C(32)$ & $-111(2)$ & $3026(2)$ & $2957(2)$ & $43(1)$ \\
\hline $\mathrm{C}(33)$ & $-299(2)$ & $3796(2)$ & $3162(2)$ & $41(1)$ \\
\hline
\end{tabular}


TABLE 2: Continued.

\begin{tabular}{lcccc}
\hline & $x$ & $y$ & $z$ & $U(\mathrm{eq})$ \\
\hline $\mathrm{C}(34)$ & $-593(2)$ & $4286(2)$ & $2558(2)$ & $36(1)$ \\
$\mathrm{C}(35)$ & $-852(2)$ & $5122(2)$ & $2600(2)$ & $36(1)$ \\
$\mathrm{C}(36)$ & $-1085(2)$ & $5405(2)$ & $3228(2)$ & $43(1)$ \\
$\mathrm{C}(37)$ & $-730(3)$ & $6084(2)$ & $3581(2)$ & $69(1)$ \\
$\mathrm{C}(38)$ & $-989(4)$ & $6347(3)$ & $4149(2)$ & $99(2)$ \\
$\mathrm{C}(39)$ & $-1589(4)$ & $5934(4)$ & $4363(2)$ & $97(2)$ \\
$\mathrm{C}(40)$ & $-1928(3)$ & $5251(3)$ & $4028(2)$ & $76(1)$ \\
$\mathrm{C}(41)$ & $-1682(2)$ & $4985(2)$ & $3458(2)$ & $52(1)$ \\
$\mathrm{C}(42)$ & $-803(2)$ & $3957(2)$ & $1218(2)$ & $36(1)$ \\
$\mathrm{C}(43)$ & $-972(2)$ & $3289(2)$ & $714(2)$ & $41(1)$ \\
$\mathrm{C}(44)$ & $-562(2)$ & $3235(2)$ & $195(2)$ & $52(1)$ \\
$\mathrm{C}(45)$ & $-735(3)$ & $2602(3)$ & $-264(2)$ & $69(1)$ \\
$\mathrm{C}(46)$ & $-1322(3)$ & $2038(3)$ & $-220(2)$ & $71(1)$ \\
$\mathrm{C}(47)$ & $-1738(2)$ & $2094(2)$ & $280(2)$ & $66(1)$ \\
$\mathrm{C}(48)$ & $-1558(2)$ & $2715(2)$ & $753(2)$ & $52(1)$ \\
$\mathrm{C}(01)$ & $3965(3)$ & $5052(3)$ & $3503(3)$ & $90(2)$ \\
$\mathrm{C}(02)$ & $3221(3)$ & $6826(3)$ & $3460(2)$ & $87(2)$ \\
$\mathrm{C}(03)$ & $2695(3)$ & $7409(3)$ & $1918(3)$ & $100(2)$ \\
$\mathrm{C}(04)$ & $3117(3)$ & $6036(4)$ & $964(2)$ & $123(3)$ \\
$\mathrm{C}(05)$ & $3879(3)$ & $4537(3)$ & $1961(4)$ & $121(2)$ \\
$\mathrm{C}(06)$ & $1396(3)$ & $4466(4)$ & $1309(2)$ & $116(2)$ \\
$\mathrm{C}(07)$ & $2153(3)$ & $2874(3)$ & $2163(3)$ & $99(2)$ \\
$\mathrm{C}(08)$ & $2390(2)$ & $3242(3)$ & $3749(2)$ & $83(2)$ \\
$\mathrm{C}(09)$ & $1782(3)$ & $5026(3)$ & $3898(2)$ & $91(2)$ \\
$\mathrm{C}(010)$ & $1180(2)$ & $5783(3)$ & $2383(3)$ & $99(2)$ \\
$\mathrm{H}(1 \mathrm{O})$ & $6370(30)$ & $3880(20)$ & $3437(12)$ & $68(14)$ \\
$\mathrm{H}(2 \mathrm{O})$ & $6210(30)$ & $5018(12)$ & $4790(20)$ & $63(14)$ \\
$\mathrm{H}(3 \mathrm{O})$ & $-1190(20)$ & $6510(20)$ & $1702(12)$ & $69(14)$ \\
$\mathrm{H}(4 \mathrm{O})$ & $-1140(30)$ & $5365(12)$ & $350(20)$ & $73(15)$ \\
$\mathrm{H}(2 \mathrm{~N})$ & $5990(20)$ & $5298(18)$ & $3791(15)$ & $59(12)$ \\
$\mathrm{H}(4 \mathrm{~N})$ & $-850(30)$ & $5080(20)$ & $1334(18)$ & $92(16)$ \\
\hline & & & &
\end{tabular}

TABLE 3: Hydrogen bonds ( $\AA$ and $\left.{ }^{\circ}\right)$ and selected bond lengths $(\AA)$ and torsion angles $\left(^{\circ}\right)$.

\begin{tabular}{llcccc}
\hline $\mathrm{D}-\mathrm{H} \cdots \mathrm{A}$ & & $d(\mathrm{D}-\mathrm{H})$ & $d(\mathrm{H} \cdots \mathrm{A})$ & $d(\mathrm{D} \cdots \mathrm{A})$ & $<(\mathrm{DHA})$ \\
\hline $\mathrm{O} 1-\mathrm{H}(1 \mathrm{O}) \cdots \mathrm{Cl} 1$ & $0.812(18)$ & $2.21(2)$ & $2.999(3)$ & $165(4)$ \\
$\mathrm{O} 2-\mathrm{H}(2 \mathrm{O}) \cdots \mathrm{Cl} 1$ & $0.821(18)$ & $2.16(2)$ & $2.965(4)$ & $167(4)$ \\
$\mathrm{O} 3-\mathrm{H}(3 \mathrm{O}) \cdots \mathrm{Cl} 2$ & $0.827(18)$ & $2.21(2)$ & $3.021(3)$ & $165(4)$ \\
$\mathrm{O} 4-\mathrm{H}(4 \mathrm{O}) \cdots \mathrm{Cl} 2$ & $0.823(19)$ & $2.14(2)$ & $2.952(3)$ & $170(4)$ \\
$\mathrm{N} 2-\mathrm{H}(2 \mathrm{~N}) \cdots \mathrm{N} 1$ & $0.902(18)$ & $1.69(2)$ & $2.574(4)$ & $164(4)$ \\
$\mathrm{N} 4-\mathrm{H}(4 \mathrm{~N}) \cdots \mathrm{N} 3$ & $0.904(19)$ & $1.71(2)$ & $2.586(4)$ & $163(4)$ \\
\hline
\end{tabular}

Selected bond lengths: O1-N1 1.390(4), O2-N2 1.374(4), O3-N3 1.392(3), O4-N4 1.374(3), N1-C11 1.283(4), N2-C18 1.289(4), N3-C35 1.286(4), N4C42 1.290(4), C6-C18 1.461(4), C10-C11 1.478(4), C30-C42 1.464(4), C34C35 1.469(4) and Cp-rings: C6-C10 1.458(4), C6-C7 1.437(4), C7-C8 1.412(4), C8-C9 1.416(5), C9-C10 1.427(4), C30-C34 1.472(4), C30-C31 1.439(4), C31-C32 1.409(4), C32-C33 1.410(5), and C33-C34 1.435(4).

Selected torsion angles: C6-C10-C11-N1 20.4(5), C10-C6-C18-N2 -14.3(5), C30-C34-C35-N3-20.4(5), and C34-C30-C42-N4 17.2(5).

bonds with $\mathrm{H}-\mathrm{Cl}$ distances between $214-221 \mathrm{pm}$, thereby preventing a supramolecular chemistry based on $\mathrm{O}-\mathrm{H}-$ O hydrogen-bonds. Nevertheless, two weak intermolecular $\mathrm{C}-\mathrm{H}-\mathrm{Cl}$ hydrogen bonds at $\mathrm{Cl}$ with distances to phenyl hydrogen atoms of 285 and $286 \mathrm{pm}$ lead to a distorted tetrahedral hydrogen coordination for Cll and build up a twodimensional sheet along the crystallographic axes (010) and (101).

\section{Conclusions}

The crystal structure of the hydrochloride of 1,2-dibenzoyl$1^{\prime}, 2^{\prime}, 3^{\prime}, 4^{\prime}, 5^{\prime}$-pentamethylruthenocene dioxime is a unique example of a protonated oxime featuring intramolecular $\mathrm{N}-$ $\mathrm{H}-\mathrm{N}$ and $\mathrm{O}-\mathrm{H}-\mathrm{Cl}$ hydrogen bonding as well as planar chirality.

\section{References}

[1] A. Chakravorty, "Structural chemistry of transition metal complexes of oximes," Coordination Chemistry Reviews, vol. 13, no. 1, pp. 1-46, 1974.

[2] V. Y. Kukushkin, D. Tudela, and A. J. L. Pombeiro, "Metal-ion assisted reactions of oximes and reactivity of oxime-containing metal complexes," Coordination Chemistry Reviews, vol. 156, pp. 333-362, 1996.

[3] J. L. Dempsey, B. S. Brunschwig, J. R. Winkler, and H. B. Gray, "Hydrogen evolution catalyzed by cobaloximes," Accounts of Chemical Research, vol. 42, no. 12, pp. 1995-2004, 1995.

[4] S. Losse, J. G. Vos, and S. Rau, "Catalytic hydrogen production at cobalt centres," Coordination Chemistry Reviews, vol. 254, no. 21-22, pp. 2492-2504, 2010.

[5] Y. Z. Voloshin, N. A. Kostromina, and R. Krämer, Clathrochelates: Synthesis, Structure and Properties, Elsevier Science, Amsterdam, The Netherlands, 2002.

[6] P. A. Jaques, V. Artero, J. Pecaut, and M. Fontecave, "Cobalt and nickel diimine-dioxime complexes as molecular electrocatalysts for hydrogen evolution with low overvoltages," Proceedings of the National Academy of Sciences (PNAS '09), vol. 106, pp. 20627-20632, 2009.

[7] O. Pantani, S. Naskar, R. Guillot, P. Millet, E. AnxolabehereMallart, and A. Aukauloo, "Cobalt clathrochelate complexes as hydrogen-producing catalysts," Angewandte Chemie, vol. 120, no. 51, pp. 10096-10098, 2008.

[8] B. Enk, H. Kopacka, K. Wurst, T. Müller, and B. Bildstein, "An efficient, modular route to new 2-Acyl-6-aminopentafulvenes and planar-chiral [N,O]-functionalized pentamethylruthenocenes," Organometallics, vol. 28, no. 18, pp. 5575-5586, 2009.

[9] B. Enk, D. Eisenstecken, H. Kopacka et al., "Doubly nfunctionalized pentafulvenes and redox-responsive $[\mathrm{N}, \mathrm{N}]-$ and [N,C,N]-pincer bis(imidoyl)pentamethylruthenocene metalloligands," Organometallics, vol. 29, no. 14, pp. 3169-3178, 2010.

[10] Z. Otwinowski and W. Minor, "Processing of X-ray diffraction data collected in oscillation mode," Methods in Enzymology, vol. 276, pp. 307-326, 1997.

[11] G. M. Sheldrick, SHELXTL V. 5. 1, Bruker Analytical X-ray Instruments, Madison, Wis, USA, 1997.

[12] E. A. Bruton, L. Brammer, F. C. Pigge, C. B. Aakeröy, and D. S. Leinen, "Hydrogen bond patterns in aromatic and aliphatic dioximes," New Journal of Chemistry, vol. 27, pp. 1084-1094, 2003.

[13] N. Tosa, A. Bende, R. A. Varga, A. Terec, I. Bratu, and I. Grosu, "H-bond-driven supramolecular architectures of the syn and anti isomers of the dioxime of bicyclo[3.3.1]nonane-3,7-dione," The Journal of Organic Chemistry, vol. 74, no. 10, pp. 3944-3947, 2009. 

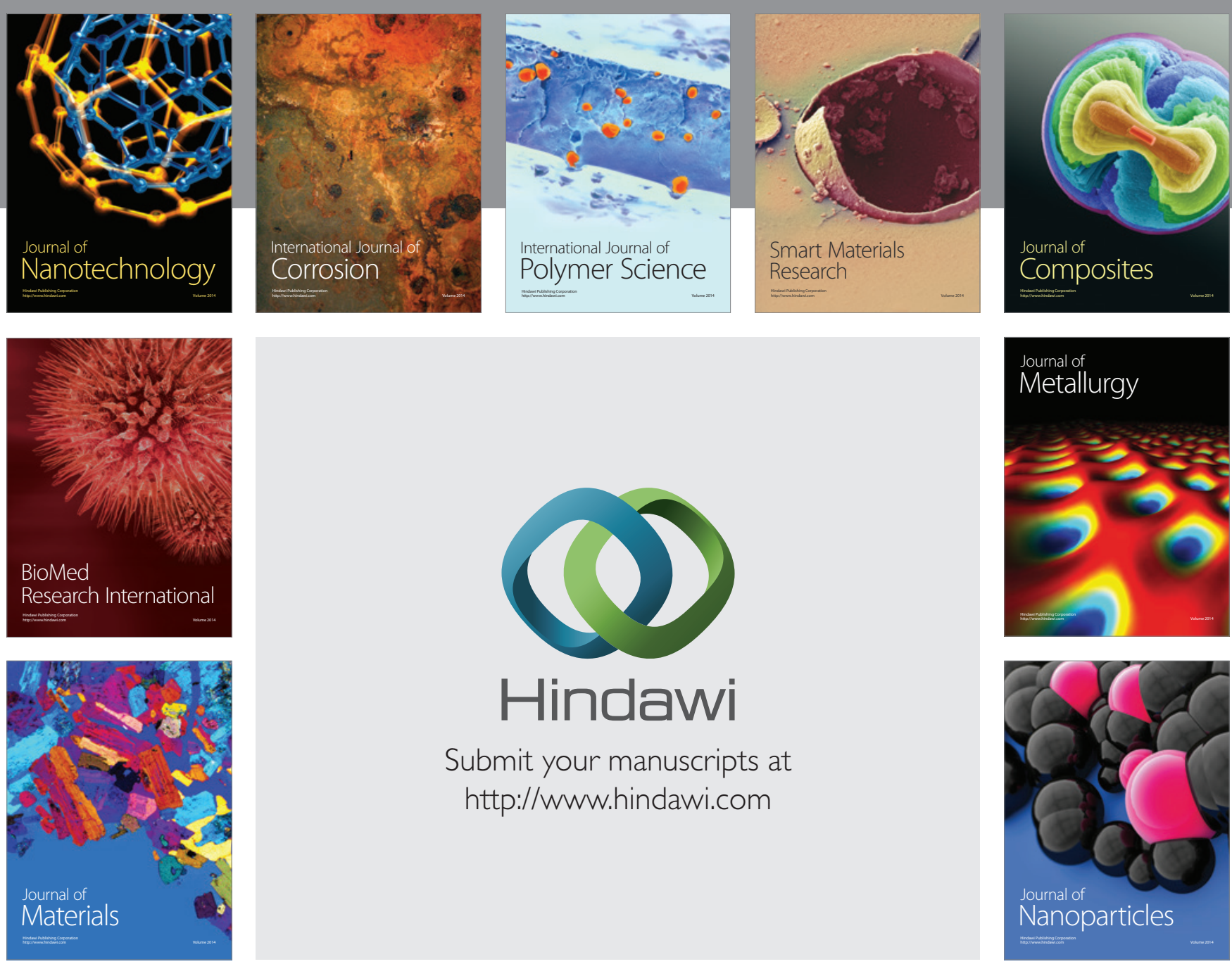

Submit your manuscripts at http://www.hindawi.com
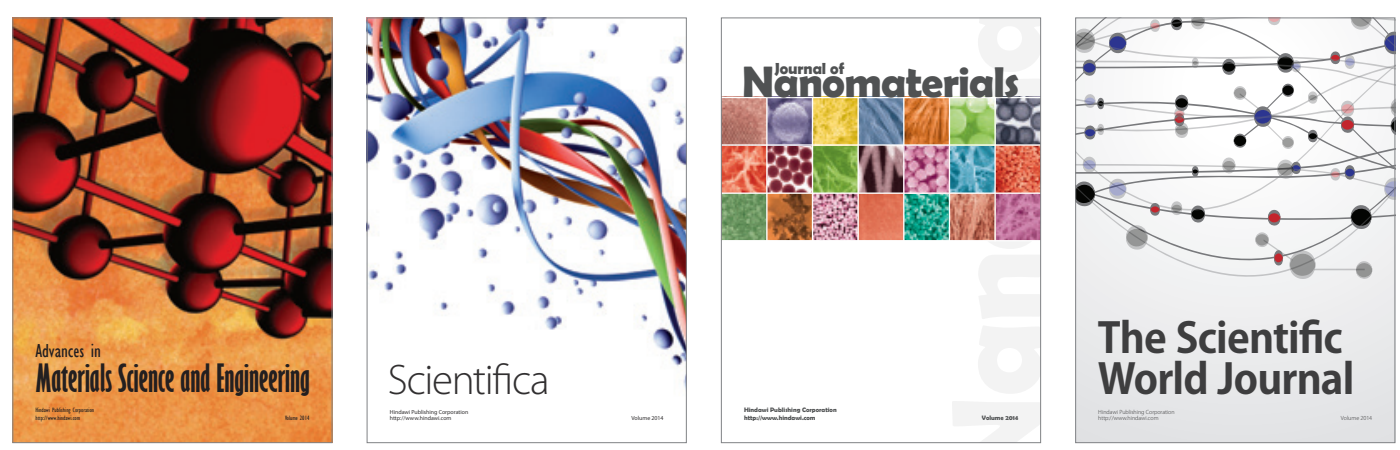

\section{The Scientific World Journal}
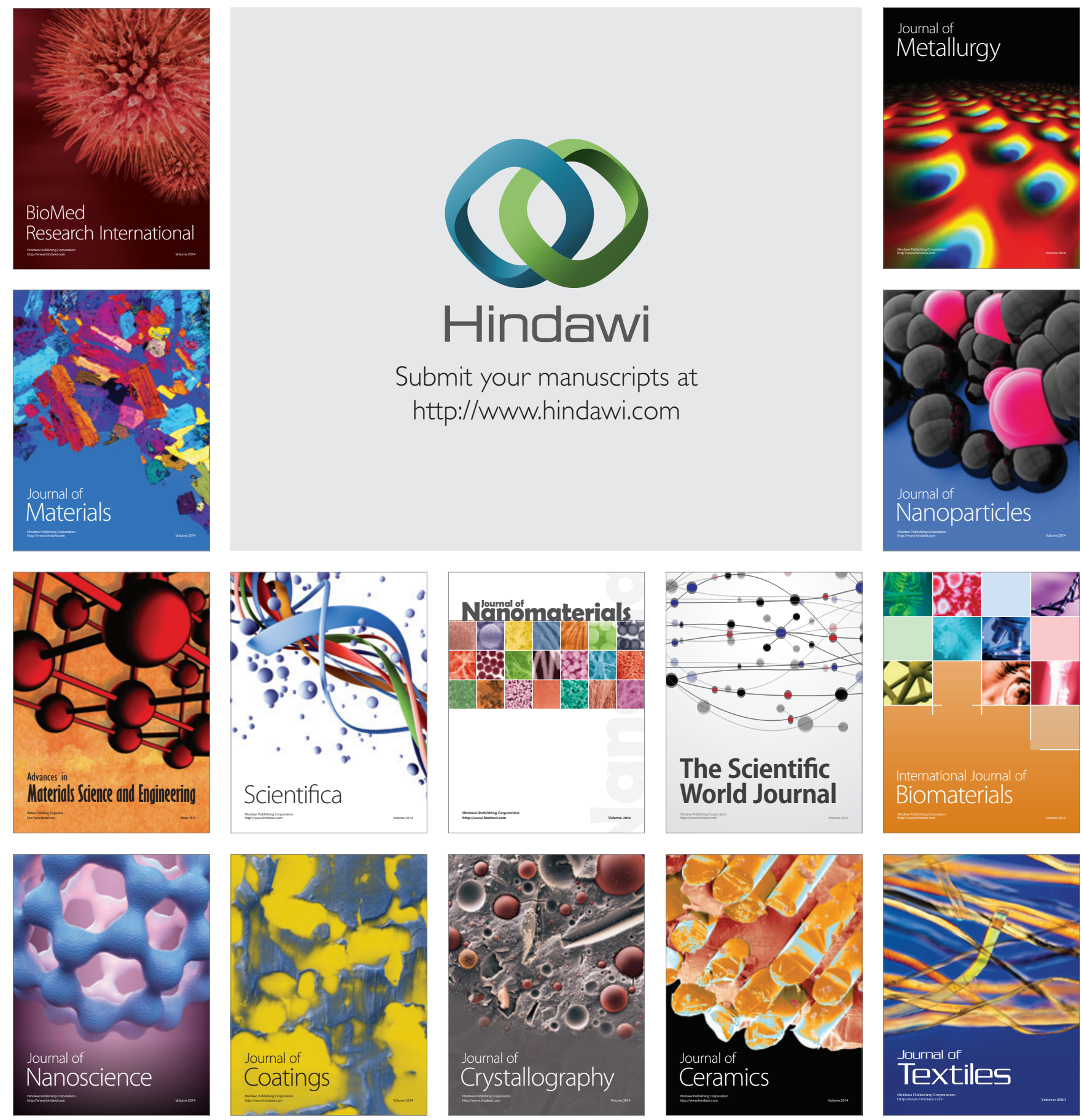